\title{
酸 New Disease Reports \\ Outbreak of stem canker and dieback of pear trees caused by Botryosphaeria obtusa (anamorph Diplodia seriata) in Turkey
}

\author{
i. Kurbetli ${ }^{1 *}$ and F. Demirci ${ }^{2}$ \\ ${ }^{1}$ Bati Akdeniz Agricultural Research Institute, 07025 Antalya, Turkey; ${ }^{2}$ Plant Protection Department, Agricultural Faculty of \\ Ankara University, Ankara, Turkey
}

*E-mail: kurbetli@gmail.com

Received: 10 Feb 2014. Published: 07 Aug 2014. Keywords: Pyrus communis, fungal plant disease

Pear (Pyrus communis) has been grown on approximately 23,500 ha in Turkey with an annual production of 462,000 tonnes, Turkey being among the top five countries for pear production in the world (Anonymous, 2013). In May 2012, losses of approximately 15\% were observed in Kayseri province associated with a decline of one- or two-year-old pear trees in an orchard containing approximately 5000 pear trees cv. Deveci. Affected trees showing a severe dieback had cankers on trunk base especially at soil level. Infected stem tissues taken from the margins of the canker were cut into small pieces $(5 \times 3 \mathrm{~mm})$ and plated onto potato dextrose agar (PDA) after surface disinfection in $1.5 \% \mathrm{NaOCl}$ for three minutes. The plates were incubated at $24^{\circ} \mathrm{C}$ for a week. Hyphae growing out from the tissue pieces were subcultured onto PDA and malt extract agar.

Fast-growing fungal colonies had abundant, white, aerial mycelia that turned grey to black with age and formed black pycnidia (Fig. 1). Ellipsoid and ovoid conidia initially hyaline and aseptate became light to dark brown and developed 1-2 septa when mature (Figs. 2,3). They measured 17.1-27.5 x 8.2-11.1 $\mu \mathrm{m}$ (mean $22.3 \times 9.7 \mu \mathrm{m}$ ). The isolates were identified as Botryosphaeria sp. according to these morphological features. After DNA extraction of an isolate, ribosomal DNA fragment amplified with ITS1 and ITS2 primers (White et al., 1990) was sequenced and the nucleotide sequence (GenBank Accession No. KC782837) had 99\% homology with Diplodia seriata isolates in GenBank (JX515708, KC020171, GU121890, EU650671, EF127892, JN607087, JQ659282, HQ288217).

Pathogenicity of the isolate was tested by stem inoculation on pear seedlings cv. Ankara. Stems and branches of four three-year-old pear seedlings were inoculated with a $6 \mathrm{~mm}$ plug from a three-day-old culture grown on PDA. Two seedlings inoculated with sterile agar plugs were used as control plants. All inoculations were sealed with wet cotton wool and wrapped with aluminium foil to prevent drying. Plants were kept in a controlled glasshouse at $25 \pm 1{ }^{\circ} \mathrm{C}$ and watered as needed. Infection with canker resulted within two weeks on basal stems and branches averaging $9.8 \mathrm{~cm}$ in length and $3.8 \mathrm{~cm}$ in width (Fig. 4). No cankers developed in the control plants except for a slight, superficial oxidation that developed on the cut surface (Fig. 4). The pathogen was reisolated from the symptomatic tissues excised from the margin of the canker and plated onto PDA. Nothing grew from the control plants.

Botryosphaeria spp. cause fruit rots, leaf spots, stem and branch cankers, gummosis, dieback and tree death of pome and stone fruit trees (Slippers $e t$ al., 2007). Diplodia seriata was isolated from trunk cankers of apple and pear trees showing dieback symptoms in South Africa (Cloete et al., 2011). $B$. obtus $a$ was the most frequently isolated species from cankers occurring on spurs, cordons or trunks of grapevines in California, USA (Urbez-Torres et al., 2006). In Turkey, B. obtusa was recovered from wood cankers of grapevines showing shoot dieback and wedge-shaped wood discolorations (Akgül et al., 2014). To our knowledge, this is the first report of Botryosphaeria obtusa (anamorph Diplodia seriata) causing disease of pear trees in Turkey, and due to the severe symptoms, it should be considered as a potential threat to pear cultivation of Turkey.

\section{References}

Akgül S, Savaş NG, Eskalen A, 2014. First report of wood canker caused Botryosphaeria obtusa, B. dothidea, Diplodia seriata, Neofusicoccum parvum and Lasiodiplodia theobromae on grapevine in Turkey. Plant Disease 98, 568. http://dx.doi.org/10.1094/PDIS-07-13-0726-PDN

Anonymous, 2013. Agricultural Production Statistics of Turkish Statistical Institute. http://tuikapp.tuik.gov.tr/bitkiselapp/bitkisel.zul (verified Feb 07, 2014).

Cloete M, Fourie PH, Damm U, Crous PW, Mostert L, 2011. Fungi associated with die-back symptoms of apple and pear trees, a possible inoculum source of grapevine trunk disease pathogens. Phytopathologia Mediterranea 50 (Supplement), S176-S190.

Slippers B, Smit WA, Crous PW, Coutinho TA, Wingfield BD, Wingfield MJ, 2007. Taxonomy, phylogeny and identification of Botryosphaeriaceae associated with pome and stone fruit trees in South Africa and other regions of the world. Plant Pathology 56, 128-139.

http://dx.doi.org/10.1111/j.1365-3059.2006.01486.x

Urbez-Torres JR, Leavitt GM, Voegel TM, Gubler WD, 2006.

Identification and istribution of Botryosphaeria spp. associated with grapevine cankers in California. Plant Disease 90, 1490-1503. http://dx.doi.org/10.1094/PD-90-1490

White TJ, Bruns T, Lee S, Taylor J, 1990. Amplification and direct sequencing of fungal ribosomal genes for phylogenetics. In: Innis MA, Gelfand DH, Shinsky J, White TJ, eds. PCR protocols. A guide to methods and applications. San Diego, CA, USA: Academic Press, 315-322.

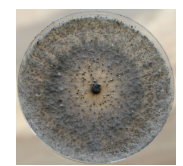

Figure 1

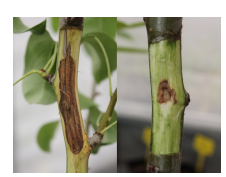

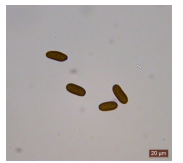

Figure 2

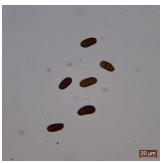

Figure 3

Figure 4

To cite this report: Kurbetli I, Demirci F, 2014. Outbreak of stem canker and dieback of pear trees caused by Botryosphaeria obtusa (anamorph Diplodia seriata) in Turkey. New Disease Reports 30, 6. http://dx.doi.org/10.5197/j.2044-0588.2014.030.006

(c) 2014 The Authors

This report was published on-line at www.ndrs.org.uk where high quality versions of the figures can be found. 